\title{
The Effects Of Sales Reports Business Intelligence On Employee Performance
}

\author{
Qurotul Aini ${ }^{1}$, Eka Purnama Harahap ${ }^{2}$, Fitri Faradilla ${ }^{3}$ \\ 1,2,3 University of Raharja, Jl. Jenderal Sudirman No.40 Modern Cikokol Tangerang \\ e-mail: aini@raharja.info, ekapurnamaharahap@raharia.info, fitri.faradilla@raharia.info
}

To cite this document:

Aini, Q., Harahap, E., \& Faradilla, F. (2019). The Effects Of Sales Reports Business Intelligence On Employee Performance. Aptisi Transactions On Management (ATM), 4(1), 83-91.

DOI:

https://doi.org/10.33050/atm.v4i1.1205

\begin{abstract}
Selling and buying activities have been done often since long ago, and this study will be discussed about the use of technological advances, especially in the field of financial management by utilizing e-commerce. When carrying out financial data collection, staff can make recapitulation by writing each transaction in the ledger, then counting the data to be the income information. However, the process is not in tune with current technological progress, because it still use a data collection process that requires a lot of time and energy. Thus, to overcome this problem, e-commerce websites are used so that it can manage finances accurately and quickly. In this study, there are 4 (four) problems that will be overcome with 2 (two) methods, and 1 (one) solution as the answer. The advantages of e-commerce website is that it has an informative viewboard regarding financial management, which can be accessed anytime and anywhere, so it is concluded that the use of ecommerce website is able to overcome the problems found in the financial management field of Raharja Internet Cafe at Perguruan Tinggi Raharja.
\end{abstract}

Keywords: Financial Management, E-Commerce, Viewboard, Raharja Internet Cafe

\section{Introduction}

Current technological advances have provided many conveniences for human activities, including in the field of trade [1,2]. In the past, to get the desired item, someone had to go to a particular shop, then make a sale and purchase transaction with the seller. However, this method requires more time and energy, causing a lack of comfort so that it is not in accordance with current technological advances [3]. Currently, the process of buying and selling can be done easily, namely by utilizing e-commerce. With e-commerce, both buyers and sellers can make transactions effectively and efficiently, saving the time and effort that causes transactions to run comfortably $[4,5]$. Buyers and sellers are also spoiled with various features provided on ecommerce websites. 


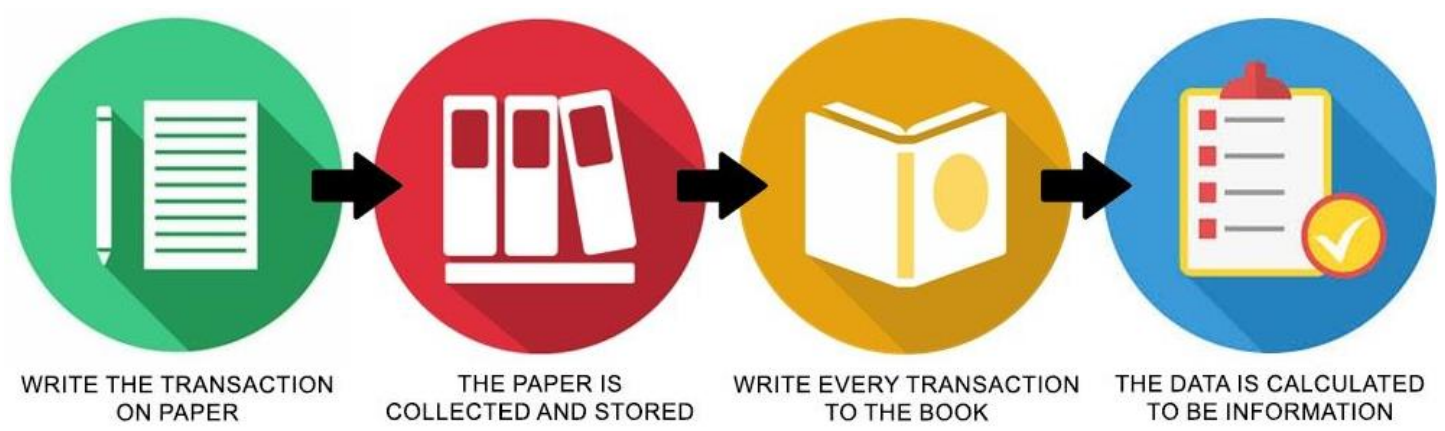

Figure 1. Conventional financial data collection

In conducting financial data collection, a seller must carefully recap every transaction so that no transaction is missed. This process requires high accuracy which takes a lot of time. In Figure 1, the flow of conventional financial data is explained. Initially, the seller must serve the buyer who made the transaction and then record it using paper media, then the transaction papers are collected and stored neatly and safely. Furthermore, the seller writes each transaction into the ledger, and the last step is to summarize the income that is closed so that it can be useful information in making decisions.

Perguruan Tinggi Raharja is a higher education that is always motivated to keep up with technological developments [6, 7]. In support of student activities, Raharja Internet Cafe was held in Perguruan Tinggi Raharja, which provided various services regarding student needs such as printing, installing, scanning, and selling various items like computer books, keyboards, USB, books etc. [8]. Even with all the advantages, Raharja Internet Cafe still has flaws, especially in the financial data collection process.

At present, the financial management process at Raharja Internet Cafe is still using paper, resulting in staff having difficulty in collecting data and delays in taking decisions by top management. For the sake of conveying information on financial data smoothly, it must have an accurate information delivery medium. Conventional ways in the financial management process must be changed in other, more sophisticated ways, so that the information presented can be easily understood by end-users and the data collection process can run smoothly [9]. Raharja Internet Cafe now has its own website, which is an e-commerce system that can be accessed by web and mobile anytime and anywhere, with a proven level of system security. With the use of the Raharja Internet Cafe website, a conventional financial data collection system can be turned into online. It is expected that with the Raharja Internet Cafe website, it can reduce barriers and increase the effectiveness of the financial management process and motivate Raharja Internet Cafe [10].

\section{Research Method}

In this study used direct observation research methods or observations. With the observation method, observations were made at Raharja Internet Cafe at Raharja College, which has implemented an e-commerce system in the transaction process of its products. After learning that the Raharja Internet Cafe website can be used as a financial data collection online, the next step is to analyze all kinds of benefits and the level of effectiveness that will be obtained if the financial data collection is applied to the Raharja Internet Cafe website [11].

Then the literature study research method is also used to support this research, by gathering several relevant research systems discussed in this study, in the form of financial management knowledge theory and e-commerce systems that are discussed or applied to various systems $[12,13,14]$. The following 10 (ten) literature studies are used in this study as a reference:

1. The research entitled "Implementasi Business Intelligence Menggunakan Highchart pada Sistem Penilaian Absensi berbasis YII Framework" conducted in 2017, by Untung Rahardja, Qurotul Aini and Alfiah Khoirunisa from Raharja College. This study discusses the implementation of business intelligence using highchart which can facilitate the supervisor in inputting attendance into highchart tables so that it is more efficient. With the use of highchart in presenting data, it makes it easier for supervisors to do attendance recapitulation from the amount of data available on structured tables and has a form that is easy to understand for end users [15].

2. The research entitled "Build a Business to Customer Online Store Using Airzone Content Management System" was conducted in 2014, by Untung Rahardja, Qurotul Aini and Desi 
Sartika from Raharja College. This study discusses the advances in technology in the world of commerce, where sales services can be done quickly in accordance with consumer demand. In the business world, online sites have facilitated buying and selling services with online transactions, known as e-commerce. Airzone is a system that uses e-commerce to do business by utilizing the internet network, using the Business to Consumer (B2C) methodology [16].

3. The study was titled "Implementation of Tangerang's Study of Baby Wise BSD's Website of Increase Online Sales of Case" conducted in 2017, by Daelami Ahmad, Hani Dewi Ariesanti and Kholipatul Awaliyah from APTISI, Budi Luhur University and STMIK Raharja. This study discusses the use of e-commerce websites at Baby Wise BSD Tangerang stores. Before the existence of e-commerce, many companies used traditional methods in marketing their products, such as using brochures or other media using paper. However, this method is not effective and requires a lot of costs. Therefore, an e-commerce website is created for the Baby Wise BSD Tangerang store, so that consumers can easily buy products whenever and wherever [17].

4. The study entitled "Pengaruh Pelayanan dan Fasilitas pada Raharja Internet Cafe Terhadap Kegiatan Perkuliahan Pada Perguruan Tinggi" conducted in 2018, by Untung Rahardja, Eka Purnama Harahap and Ririn Eka Cipta Devi from Raharja College. This study discusses the quality of service at Raharja Internet Cafe, a facility within the Raharja College that provides a variety of products to help students, such as computer use, scan, print, and lecture tools. In order to obtain data regarding the quality of service at Raharja Internet Cafe, an online questionnaire was given to 30 (thirty) visitors, and an average of $85.42 \%$ was obtained in the benefits section. So it can be concluded that Raharja Internet Cafe provides benefits in helping student lecture activities [18].

5. The study entitled "Web-Based Clothing Sales Information System:" Bluelight Distro "which was conducted in 2017, by Nina Rahayu, Fauziyyah Husna Nurdiayanah Lestari and Ulfa Tiana Aprilyani from Raharja College. This study discusses the application of website-based clothing sales, with the aim of making it easier for consumers to find clothes accompanied by information, prices and ordering methods. Previously, consumers had to go to a shop to do a transaction, and this method requires more time and cost, thus reducing the practicality of the transaction process. The results of the study show that e-commerce websites can be used by consumers as an alternative medium for purchasing clothes, as well as a medium of communication with sellers [19].

6. The study entitled "Analysis of the Role of Internet Technology as a Media for E-Commerce Transactions in Improving Economic Development" conducted in 2015, by Yulianto, Fifit Alfiah, Eka Purnama Harahap, Baiq Aneji Pahad, Andriyanto, Ian An Azhari and Riyan Sindi Saputra from the University Raharja height. This study discusses the good impact of technological developments in the business field. E-commerce business actors consist of various groups, and for students, business experience using e-commerce can be used as a benchmark to create young people who are innovative, productive and independent. Based on the survey results, it is evident that the development of e-commerce is strongly influenced by technological developments [20].

7. The study entitled "An Investigation of the Impact of Effective Factors on the Success of ECommerce in Small-and Medium-Sized Companies" conducted in 2016, by Mahdi Choshin and Ali Ghaffari from the Institute of Mizan and Islamic Azad University. This study discusses the management strategy of a company in controlling the buyer so that it can survive in the world of trade. One strategy is to use e-commerce, which can be used in sales, marketing and services online. However, e-commerce has many factors that influence success from within and outside the organization [21].

8. The research entitled "Designing an Agent for Information Extraction from Persian E-Shops" conducted in 2018, by Nasrin Rasouli, Lela Abedi and Sara Ghaei from Islamic Azad University and Computer Group. This study discusses about E-shops which is one of e-commerce. Often when searching for products, the results that appear are not in accordance with the intended, such as different product descriptions and product forms that are not suitable. Constraints in product search result in difficulties for buyers, therefore a software is created that can extract product information, which buyers can use to compare seller conditions and prices [22].

9. Penelitian dengan judul "Pembinaan Pengelolaan Manajemen Usaha dan E-Marketing pada Pelaku Usaha Industri Mikro Pengrajin Sepatu di Kecamatan Medan Denai" yang dilakukan pada tahun 2017, oleh Muhammad Irfan Nasution, Muhammad Andi Prayogi dan Satria Mirsya Affandy Nasution dari Universitas Muhammadiyah Sumatera Utara. This study discusses about community service activities aimed at fostering e-marketing and business management to shoe 
craftsmen. Conducted for 8 (eight) months with the main output target is obtaining a business license, publicizing scientific journal public service, having a website and improving insight and skills. [23].

10.The research entitled "Penerapan Viewboard Rooster Berbasis Bootstrap Sebagai Penunjang Pelayanan iDuhelp! Pada Perguruan Tinggi" conducted in 2018, by Erick Febriyanto, Yulianto and Fauziyyah Husna Nurdiayanah Lestari from STMIK Raharja Tangerang. This study discusses information service facilities at Perguruan Tinggi Raharja, namely as Role Online System Ticketing (ROOSTER). The way the service works with ROOSTER is to use a ticket that will be given to the related party, where the related party will provide accurate information in the service of iDuhelp!, a facility for answering about college information. This study aims to develop the ROOSTER system viewboard which previously still displays inaccurate data making it difficult for end-users like staff, operator and admin. The results of this study are to obtain an informative viewboard in ROOSTER system, so that it can provide a reliable information [24].

Based on 10 (ten) literature studies described above, it can be concluded that the current buying and selling system has been highly developed with e-commerce. Besides having a positive impact on the buying and selling process, e-commerce also makes it easier for sellers to carry out financial management in a more practical and fast way.

\section{Results and Analysis}

The role of e-commerce in bridging the seller with the buyer is very important, therefore for the smooth process of buying and selling in this age, a seller must utilize and adapt to all available facilities. Financial management is part of the top management task with the main responsibilities of important decisions regarding financing and investation [25]. Raharja Internet Cafe website also has organized financial management, which is carried out by top management and reported by staff within a certain period of time.

\subsection{Analysis of Problems}

As explained in the previous explanation, Raharja Internet Cafe is a facility that provides a variety of services for students in meeting their lecture needs. However, there are still some problems that need to be addressed in order to support financial management activities. Currently there are 4 (four) problems in the financial management process on the Raharja Internet Cafe website. The first problem is, the financial recording process at Raharja Internet Cafe still uses paper media, namely the ledger. The use of this paper is not recommended because it can cause problems such as paper loss. Then the second problem is, spending more on buying notes and ledgers. The third problem is, it requires high accuracy in recording financial data collection. Then the last problem is the fourth problem, the slow process of recording so that top management is hampered in making important decisions.

\subsection{Program Design}

To overcome the problem, one of the methods used is to maintain the Raharja Internet Cafe website, so that sellers and buyers can transact without problems, and sellers can record transactions smoothly [26]. Website maintenance by the admin such as adding upto-date information and product prices must also be carried out, thus entering product sales data accurately and incorrectly [27]. As a result, the financial data collection process has the necessary support, and financial management can be guaranteed. 


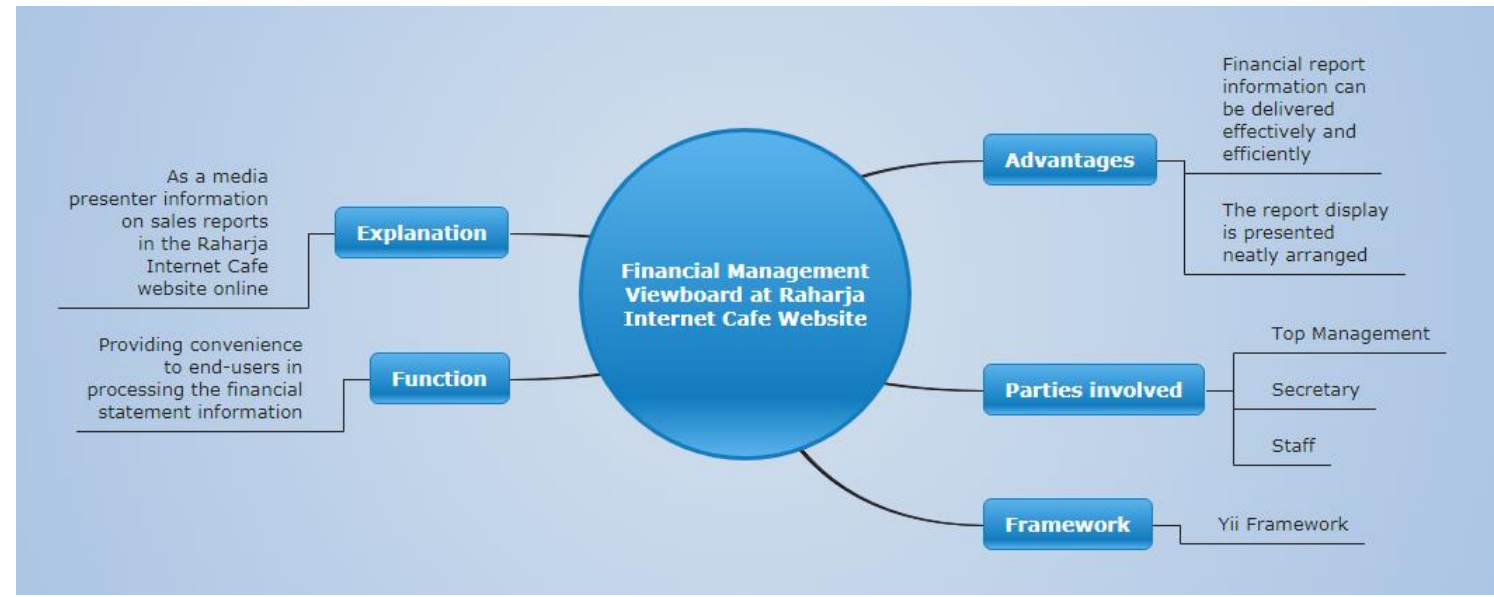

Figure 2. Mind map

Figure 2 is a view of the mind map that describes the viewboard of financial management on the Raharja Internet Cafe website, which consists of: (1) Explanation: as a media presenter information about the sales report on Raharja Internet Cafe website online. (2) Functions: provide convenience to end-users in processing financial statement information. (3) Advantages: financial report information can be conveyed effectively and efficiently, and the appearance of the report presented is neatly arranged. (4) Parties involved: top management, secretary and staff. (5) Framework: Yii Framework.

\subsection{Flowchart Alghorithm}

After examining the problems that exist in the current financial management system, the process flow of looking at financial statements using the Raharja Internet Cafe viewboard that is carried out by the end-user can be illustrated in the following flowchart:

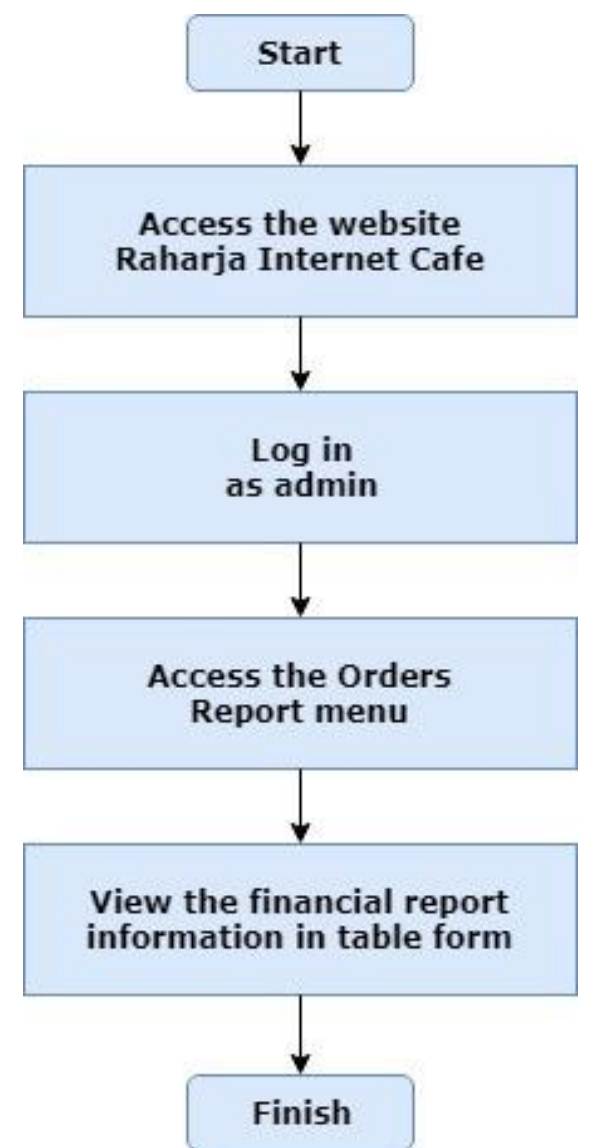

Figure 3. Flowchart of view the report 
In Figure 3, we describe 4 (four) steps of the process of viewing the financial statements on the Raharja Internet Cafe website online, as follows: (1) End-users access the Raharja Internet Cafe website. (2) End-users log in as admin. (3) End-users access the Orders Report menu. (4) End-users view financial statement information in table form [28].

\subsection{Implementation}

There are many electronic media that can be used to access the Raharja Internet Cafe website, such as personal computers, laptops, notebooks, tablets and cellphones. All of these media can be used to access when accompanied by support from an internet connection. In addition, the appearance of the eye-catching and neatly arranged Raharja Internet Cafe website has a positive impact on the end-users who come to visit. In addition, Raharja Internet Cafe's back office is also easy to use and the appearance has summarized important things in order and uses tables.

The result of the research is an informative viewboard that can be accessed on https://ric.raharja.info/ after logging in as an admin. The viewboard has a function to display various types of financial reports on Raharja Internet Cafe with grouping based on several criteria.

\begin{tabular}{|c|c|c|c|c|c|c|c|c|c|c|}
\hline csv & Excel & Print & & \multicolumn{7}{|c|}{ Search: } \\
\hline No & Nama & Tanggal & Produk & aty & Harga & Diskon & Jumlah & Modal & Total Modal & Keuntungan \\
\hline 1 & Dyah Ayu & $10 / 26 / 2018$ & Scan Print & 1 & Rp 2000 & 0 & Rp 2000 & Rp 500 & Rp 500 & Rp 1500 \\
\hline 2 & Dyah Ayu & $10 / 26 / 2018$ & Print Warna A4 & 6 & Rp 600 & 0 & $\operatorname{Rp} 3600$ & Rp 164 & Rp 984 & Rp 2616 \\
\hline 3 & Ghina Okta & $10 / 26 / 2018$ & Frestea $220 \mathrm{ml}$ & 5 & Rp 3000 & 0 & Rp 15000 & Rp 1667 & Rp 8335 & Rp 6665 \\
\hline 4 & Ghina Okta & $10 / 26 / 2018$ & Scan & 2 & Rp 1500 & 0 & $\operatorname{Rp} 3000$ & Rp 0 & $\operatorname{Rp} 0$ & Rp 3000 \\
\hline 5 & Ghina Okta & $10 / 26 / 2018$ & Print Hitam Putih A4 (1-5 Lembar) & 2 & $\operatorname{Rp} 350$ & 0 & Rp 700 & $\operatorname{Rp} 200$ & $\mathrm{Rp} 400$ & $\operatorname{Rp} 300$ \\
\hline 6 & Febby Arsy & $10 / 26 / 2018$ & Ades $(600 \mathrm{ml})$ & 1 & $\operatorname{Rp} 3000$ & 0 & $\operatorname{Rp} 3000$ & $\operatorname{Rp} 2000$ & Rp 2000 & Rp 1000 \\
\hline 7 & Imelda Putri & $10 / 26 / 2018$ & Print Hitam Putih A4 (5-500 Lembar) & 26 & $\operatorname{Rp} 300$ & 0 & Rp 7800 & Rp 200 & Rp 5200 & Rp 2600 \\
\hline 8 & Imelda Putri & $10 / 26 / 2018$ & Print Warna F4 & 2 & Rp 700 & 0 & Rp 1400 & Rp 175 & $\operatorname{Rp} 350$ & Rp 1050 \\
\hline 9 & Saraswati & $10 / 25 / 2018$ & FANTA Strawberry $(390 \mathrm{ml})$ & 1 & Rp 5000 & 0 & Rp 5000 & Rp 3950 & Rp 3950 & Rp 1050 \\
\hline 10 & Saraswati & $10 / 25 / 2018$ & Print Hitam Putih A4 (1-5 Lembar) & 9 & $\operatorname{Rp} 350$ & 0 & Rp 3150 & Rp 200 & Rp 1800 & Rp 1350 \\
\hline
\end{tabular}

Figure 4. Table of financial statements per product

Seen in Figure 4, information about sales in the form of financial report tables per product is displayed on the Raharja Internet Cafe viewboard. In the table, there are 11 (eleven) columns namely number, name, date, product, quantity, price, discount, amount, capital, total capital and profit. In addition, there are also 3 (three) buttons to download in different formats, namely CSV, Excel and Print formats. A search column is also displayed to facilitate product search. The table of financial statements per product besides providing information about the products sold in detail, can also be a source of information in checking product stock.

\begin{tabular}{|c|c|c|c|c|c|c|c|c|}
\hline $\operatorname{csv}$ & Excel & Print & & & Search & & & \\
\hline No & \multicolumn{2}{|c|}{ Kategori } & Qty & Jumlah Pemasukan & Total Modal & \multicolumn{3}{|c|}{ Keuntungan } \\
\hline 1 & \multicolumn{2}{|c|}{ Accessories } & 4 & Rp 230.000 & Rp 170.000 & \multicolumn{3}{|c|}{ Rp 60.000} \\
\hline 2 & & ATK & 530 & Rp 1.289 .000 & Rp 662.000 & \multicolumn{3}{|c|}{ Rp 627.000} \\
\hline 3 & & tal iPad & 5 & Rp 175.000 & Rp 56.000 & \multicolumn{3}{|c|}{ Rp 119.000} \\
\hline 4 & & inuman & 447 & Rp 1.727.000 & Rp 1.201.000 & \multicolumn{3}{|c|}{ Rp 526.000} \\
\hline 5 & & Print & 8102 & Rp 3.534 .000 & Rp 1.570 .000 & \multicolumn{3}{|c|}{ Rp 1.964.000 } \\
\hline 6 & Rah & rja Career & 2 & Rp 15.000 & Rp 11.000 & \multicolumn{3}{|c|}{ Rp 4.000} \\
\hline
\end{tabular}

Figure 5. Table of financial statements per category 
Based on Figure 5, information about sales in the form of financial report tables per category on the viewboard Raharja Internet Cafe is displayed. In the table, there are 6 (six) columns namely number, category, quantity, amount of income, total capital and profits. In addition, in this table there are also 3 (three) buttons to download in different formats, namely CSV, Excel and Print. A search column is also displayed to make it easier to search for categories. The financial report table per this category provides information about the categories that are sold in detail, so that it can be used as a basis for decision making regarding the categories, which ones will be maintained, improved or stopped by referring to the profits obtained.

\begin{tabular}{|c|c|c|c|c|c|c|}
\hline $\operatorname{csv}$ & Print & & & \multicolumn{3}{|c|}{ Search: } \\
\hline Bulan & Jumlah Pemasukan & Total Modal & Keuntungan & Presentasi RIC 70\% & Presentasi Mahasiswa 30\% & Infaq $2.5 \%$ \\
\hline Mei & Rp 2.000 .000 & Rp 1.000 .000 & Rp 1.000 .000 & $\operatorname{Rp} 700.000$ & $\operatorname{Rp} 300.000$ & Rp 25.000 \\
\hline Juni & Rp 600.000 & $\operatorname{Rp} 300.000$ & $\operatorname{Rp} 300.000$ & Rp 210.000 & Rp 90.000 & $\operatorname{Rp} 7.500$ \\
\hline Juli & Rp 4.000 .000 & $\operatorname{Rp} 2.000 .000$ & Rp 2.000 .000 & $\operatorname{Rp} 1.400 .000$ & Rp 600.000 & Rp 50.000 \\
\hline Agustus & $\operatorname{Rp} 5.000 .000$ & Rp 4.000 .000 & Rp 1.000 .000 & Rp 700.000 & $\operatorname{Rp} 300.000$ & Rp 25.000 \\
\hline September & Rp 8.000 .000 & Rp 5.000 .000 & $\operatorname{Rp} 3.000 .000$ & Rp 2.100 .000 & Rp 900.000 & Rp 75.000 \\
\hline Oktober & Rp 6.000.000 & $\operatorname{Rp} 3.000 .000$ & $\operatorname{Rp} 3.000 .000$ & $\operatorname{Rp} 2.100 .000$ & Rp 900.000 & Rp 75.000 \\
\hline
\end{tabular}

Figure 6. Table of financial statements per month

In Figure 6, information about sales in the form of monthly financial report tables on the Raharja Internet Cafe viewboard is displayed. In the table, there are 7 (seven) columns namely month, total income, total capital, profit, RIC presentation $70 \%$, student presentation $30 \%$, and infaq $2.5 \%$. Then, in this table there are also 3 (three) buttons to download in different formats, namely in CSV, Excel and Print formats. A search column is also displayed to make it easier to search for the moon. This monthly financial statement table provides information on various types of financial income calculations, so that it can be used as a basis for decision making regarding the month.

\begin{tabular}{|c|c|c|c|c|c|c|}
\hline $\operatorname{csv}$ & Excel & Print & & & Search: & \\
\hline No & \multicolumn{2}{|c|}{ Tanggal } & Qty & Jumlah Pemasukan & Total Modal & Keuntungan \\
\hline 1 & \multicolumn{2}{|c|}{$10 / 26 / 2018$} & 95 & Rp 700.000 & Rp 500.000 & Rp 200.000 \\
\hline 2 & \multicolumn{2}{|c|}{$10 / 25 / 2018$} & 71 & Rp 500.000 & Rp 300.000 & Rp 200.000 \\
\hline 3 & \multicolumn{2}{|c|}{$10 / 24 / 2018$} & 256 & Rp 900.000 & Rp 600.000 & Rp 300.000 \\
\hline 4 & \multicolumn{2}{|c|}{$10 / 23 / 2018$} & 115 & Rp 800.000 & Rp 700.000 & Rp 100.000 \\
\hline 5 & \multicolumn{2}{|c|}{$10 / 22 / 2018$} & 99 & Rp 700.000 & Rp 400.000 & Rp 300.000 \\
\hline
\end{tabular}

Showing 1 to 6 of 6 entries

Previous Next

Figure 7. Table of financial statements per day

Then the last one is Figure 7, showing information about sales in the form of financial statement tables per day on the Raharja Internet Cafe viewboard. In the table, there are 6 (six) columns, namely number, date, quantity, amount of income, total capital and profits. In addition, this table also has 3 (three) buttons to download reports in different formats, namely CSV, Excel and Print. There is also a search column to make it easier to search for days by date. This financial report table provides information about the amount of income, capital and profits sold in detail over a period of time per day, so that it can be used as a basis for making decisions regarding which days are crowded or quiet. 


\section{Conclusion}

Based on the viewboard described earlier, it can be concluded that 4 (four) conclusions that with the implementation of the viewboard accompanied by an informative table, can provide progress in the financial management process of Raharja Internet Cafe, namely the reporting process that is applied to be more effective and efficient, because with viewboard on the Raharja Internet Cafe website can reduce paper usage drastically and reports can be well documented. Then the expenses for financial management can be saved, because now they no longer need notes or ledgers in the financial recording process. Then the possibility of human error can be minimized, because the financial report data input process with the Raharja Internet Cafe website does not require high accuracy as when inputting data using general ledger media. And the last is the reporting process can run quickly because the transactions that have been completed will automatically be recorded in the financial statements in the form of tables in the viewboard. So top management and staff can make the right decisions in a fast period of time.

\section{References}

[1] Rahardja, U., Aini, Q., \& Sulastrini, L. R. (2017). Penerapan Inbound Official Site Sistem Informasi Untuk Meningkatkan Rank Webometrics. Technomedia Journal, 1(2), 106-117.

[2] Rahardja, U., Aini, Q., \& Meytasari, R. (2017). Pemanfaatan Fungsi Etalase Artikel Untuk Meningkatkan Traffic Rank Website ZPreneur. Technomedia Journal, 1(2), 75-89.

[3] U. Rahardja, "Artificial informatics," 2009 4th IEEE Conference on Industrial Electronics and Applications, Xi'an, 2009, pp. 3064-3067.

[4] Aini, Q., Febriyanto, E., \& Pratama, D. (2017, August). PENERAPAN TEKNIK GAMIFIKASI DALAM BENTUK SENDING GIFTSUNTUK MENINGKATKAN TRAFFIC RANK. In SISITI: Seminar IImiah Sistem Informasi dan Teknologi Informasi (Vol. 5, No. 1).

[5] Rahardja, U., Yusup, M., \& Aini, Q. (2014). Aplikasi Campus Learning System iOU (integrated Online Ujian) Dalam Mendukung Kegiatan iLearning Education (iDu) Pada Perguruan Tinggi. CCIT Journal, 7(3), 368-383.

[6] Ariessanti, H. D., \& Aini, Q. (2017). Penerapan iDu iLearning Plus berbasis Gamification Sebagai Media Pembelajaran Jarak Jauh pada Perguruan Tinggi. Technomedia Journal, 1(2), 37-50.

[7] Sunarya, P.A. \& Rahardja, Untung \& Desrianti, D.I.. (2016). Development assessment module portfolio e-IMEi students with learning to improve the quality of concentration case study mavib. 13. 3597-3606.

[8] Rahardja, U., Harahap, E. P., \& Pratiwi, D. I. (2018). Pemanfaatan RinfoSheet Sebagai Media Informasi Laporan Penjualan Barang pada Raharja Internet Cafe. Jurnal IImiah Teknologi Informasi Asia, 12(1), 65-74.

[9] Djatmiko, B., \& Husain, A. (2017). Analyze and Record a Series of Corporate Sales Transactions On Web Based Accounting Online System. Aptisi Transactions of Management (ATM), 1(2), 110122.

[10] Rahardja, U., Moein, A., \& Lutfiani, N. Leadership, Competency, Working Motivation and Performance of High Private Education Lecturer with Institution Accreditation B: Area Kopertis IV Banten Province. Man India, 97(24), 179-192.

[11] Azizah, N., Supriyanti, D., \& Astriyani, E. (2017). The Role of Web Based Accounting Online System 2.0 as the Company's Income and Expense Management. Aptisi Transactions of Management (ATM), 1(1), 48-53.

[12] Rahardja, U., Aini, Q., \& Putri, D. M. (2018). Pemanfaatan Automated Email System (AEMS) Sebagai Media Notifikasi Penilaian Hasil Belajar. SENSITEK, 1(1), 49-54.

[13] Rahardja, U., Aini, Q., \& Santoso, N. P. L. (2018). Pengintegrasian YII Framework Berbasis API pada Sistem Penilaian Absensi. SISFOTENIKA, 8(2), 140-152.

[14] Rahardja, U., Aini, Q., \& Khoirunisa, A. (2017). Implementasi Business Intelligence Menggunakan Highchart pada Sistem Penilaian Absensi berbasis YII Framework. CSRID (Computer Science Research and Its Development Journal), 9(2), 115-124.

[15] Rahardja, U., Harahap, E. P., \& Dewi, S. R. (2019). The Strategy of Enhancing Article Citation and $\mathrm{H}$-Index on SINTA to Improve Tertiary Reputation. TELKOMNIKA (Telecommunication Computing Electronics and Control), 17(2).

[16] Rahardja, U., Aini, Q., \& Sartika, D. (2015). Build A Business To Customer Online Store Using Airzone Content Management System. CCIT Journal, 8(2), 112-122. 
[17] Ahmad, D., Ariesanti, H. D., \& Awaliyah, K. (2017). Implementation of E-Commerce Website to Increase Online Sales of Case Study of Baby Wise BSD Tangerang. Aptisi Transactions of Management (ATM), 1(1), 11-17.

[18] Devi, R. E. C., Rahardja, U., \& Harahap, E. P. (2018). Pengaruh Pelayanan dan Fasilitas pada Raharja Internet Cafe Terhadap Kegiatan Perkuliahan Pada Perguruan Tinggi. Jurnal Teknoinfo, 12(2), 23-28.

[19] Rahayu, N., Lestari, F. H. N., \& Aprilyani, U. T. (2017). Clothing Sales Information System WebBased:"Bluelight Distro". VOLT: Jurnal IImiah Pendidikan Teknik Elektro, 2(1), 55-62.

[20] Yulianto, Y., Alfiah, F., Harahap, E. P., Pahad, B. A., Andriyanto, A., Azhari, I. A., \& Saputra, R. S. (2015). Analisa Peranan Teknologi Internet Sebagai Media Transaksi E-Commerce Dalam Meningkatkan Perkembangan Ekonomi. SEMNASTEKNOMEDIA ONLINE, 3(1), 4-1.

[21] Choshin, M., \& Ghaffari, A. (2017). An investigation of the impact of effective factors on the success of e-commerce in small-and medium-sized companies. Computers in Human Behavior, $66,67-74$.

[22] Rasouli, N., Abedi, L., \& Ghaei, S. (2018). Designing an Agent for Information Extraction from Persian E-shops. TELKOMNIKA, 16(1), 455-462.

[23] Nasution, M. I., Prayogi, M. A., \& Nasution, S. M. A. (2017). Pembinaan Pengelolaan Manajemen Usaha Dan E-Marketing Pada Pelaku Usaha Industri Mikro Pengrajin Sepatu Di Kecamatan Medan Denai. JURNAL PENGABDIAN KEPADA MASYARAKAT, 23(2), 292-299.

[24] Febriyanto, E., \& Yulianto, F. H. N. L. (2018). Penerapan Viewboard Rooster Berbasis Bootstrap Sebagai Penunjang Pelayanan iDuhelp! Pada Perguruan Tinggi. Jurnal Ilmiah Teknologi Informasi Asia, 12(2).

[25] Setia Mulyawan, S. (2015). Manajemen Keuangan.

[26] Rahardja, U., Aini, Q., \& Faradilla, F. (2018). Implementasi Viewboard Berbasis Interaktif Javascript Charts Pada Sistem Penilaian Perkuliahan. Jurnal IImiah Teknologi Informasi Asia, 12(2), 91-102.

[27] Sunarya, A., Rafika, A. S., \& Rahayu, S. (2017). Analyze and Record a series of Purchase Transactions on Companies using Online Accounting Software. Aptisi Transactions of Management (ATM), 1(1), 42-47.

[28] Rahardja, U., Aini, Q., \& Faradilla, F. (2018). IMPLEMENTASI VIEWBOARD BERBASIS INTERAKTIF JAVASCRIPT CHARTS PADA WEBSITE E-COMMERCE PERGURUAN TINGGI. Jurnal Dinamika Informatika, 7(2), 1-17. 